\title{
DAMPAK ALIH FUNGSI LAHAN PERTANIAN CENGKEH TERHADAP KONDISI SOSIAL EKONOMI PETANI (Studi Kasus Petani Pemilik Lahan di Kelurahan Kumelembuai Kecamatan Tomohon Timur)
}

\author{
River Pieter Tandaju \\ Elsje P. Manginsela \\ Nordy F. L. Waney
}

\begin{abstract}
The research aims to describe the impact of the conversion of agricultural land of cloves to the socio-economic condition of farmers. The study was conducted from May to July 2017. The data used are primary data obtained through interviews to 5 (five) respondents who sell land for land converted. Secondary data is obtained from Tetetana Hill nature reserve, Kumelembuai village government, books and journals. Data analysis used is descriptive analysis. The research results showed that viewed from the economic side, land conversion has a positive impact for the farmers family and local society. Positive impacts for farmers family include increasing the income, helping to construction the house of farmers, opening up a new farming businesses, and for local society like existence of jobs. Viewed from the social side, land conversion has positive and negative impacts, that is: change of farmers family life status (positive impact), and the influence of visitor habits toward society (negative impact).
\end{abstract}

Keywords: social economy impact, land conversion, East Tomohon Sub-district, Tomohon City.

\begin{abstract}
ABSTRAK
Penelitian bertujuan untuk mendeskripsikan dampak alih fungsi lahan pertanian cengkeh terhadap kondisi sosial ekonomi petani pemilik lahan. Penelitian dilaksanakan pada bulan Mei sampai Juli 2017. Data primer diperoleh melalui wawancara kepada 5 (lima) responden pemilik lahan yang menjual lahan untuk dialihfungsikan. Data sekunder diperoleh dari Kantor lokasi wisata alam Bukit Tetetana, Pemerintah Kelurahan Kumelembuai, buku dan jurnal. Analisis data yang digunakan yaitu Analisis Deskriptif. Hasil penelitian menunjukan bahwa dilihat dari sisi ekonomi, alih fungsi lahan memiliki dampak positif bagi keluarga petani penjual dan masyarakat sekitar. Dampak positif bagi keluarga petani antara lain meningkatkan pendapatan keluarga petani, pembangunan rumah keluarga petani, membuka usaha pertanian baru bagi keluarga petani, dan untuk masyarakat sekitar adanya peluang kerja. Dilihat dari sisi sosial, alih fungsi lahan memiliki dampak positif dan negatif yaitu: perubahan status hidup keluarga petani (dampak positif), dan pengaruh kebiasaan buruk dari pengunjung terhadap masyarakat (dampak negatif ).
\end{abstract}

Kata Kunci: dampak ekonomi sosial, alih fungsi lahan, Kecamatan Tomohon Timur, Kota Tomohon. 


\section{PENDAHULUAN}

\section{Latar Belakang}

Indonesia adalah negara dengan kepadatan penduduk ke 4 di dunia. Penduduk di Indonesia, berdasarkan data Badan Pusat Statistik (BPS), pada tahun 2015 adalah 254.9 juta jiwa. Pertumbuhan penduduk di Indonesia adalah $1,3 \%$ per tahun atau 3 juta orang per tahun. Seiring dengan bertambahnya jumlah penduduk maka kebutuhan akan lahan juga bertambah.

Lahan menjadi salah satu unsur utama dalam menunjang kehidupan manusia, hampir semua sektor pembangunan memerlukan lahan, seperti sektor pertanian, kehutanan, perumahan, industri, pertambangan transportasi dan pariwisata. Banyaknya kegiatan kegiatan pembangunan yang dilakukan tanpa melihat keterbatasan lahan yang ada, akan berpotensi menimbulkan masalah dan akan memicu penggunaan lahan dari satu penggunaan ke penggunaan lainnya atau yang disebut alih fungsi lahan.

Alih fungsi lahan adalah perubahan fungsi sebagian atau seluruh kawasan lahan dari fungsinya semula (seperti yang direncanakan) menjadi fungsi lain yang berpotensi menimbulkan dampak negatif (masalah) terhadap lingkungan dan potensi lahan itu sendiri. Alih fungsi lahan akan terjadi terus menerus yang disebabkan oleh semakin meningkatnya kebutuhan lahan seperti: pemukiman, industri, perkantoran, tempat wisata, jalan raya dan infrastruktur lain untuk menunjang perkembangan masyarakat (Lestari, 2010).

Proses alih fungsi lahan pertanian ke penggunaan non pertanian yang terjadi disebabkan oleh beberapa faktor. Menurut Lestari, (2010) ada tiga faktor yang menyebabkan terjadinya konversi lahan pertanian yaitu :

1. Faktor eksternal merupakan faktor yang disebabkan oleh adanya dinamika pertumbuhan perkotaan dan pertumbuhan penduduk, demografi maupun ekonomi.

2. Faktor internal merupakan faktor yang lebih melihat sisi yang disebabkan oleh kondisi sosial-ekonomi rumah tangga pertanian pengguna lahan.

3. Faktor kebijakan merupakan aspek regulasi yang dikeluarkan oleh pemerintah pusat maupun daerah yang berkaitan dengan perubahan fungsi lahan pertanian.

Sulawesi Utara, merupakan salah satu Provinsi yang terus mengalami perkembangan pembangunan di semua sektor, salah satunya sektor pariwisata. Pariwisata yang sedang digemari di Sulawesi Utara saat ini adalah Wisata alam. Salah satunya adalah Wisata alam yang berada di Kelurahan Kumelembuai Kota Tomohon. Wisata alam ini bernama Bukit Tetetana. Wisata alam ini berada di dataran tinggi, di kawasan perkebunan warga Kumelembuai, berada di atas bukit dan dipadukan dengan pemandangan Kota Manado, Minahasa Utara, dan Kota Bitung.

Wisata alam Bukit Tetetana saat ini sedang dalam pembangunan. Wisata alam ini dulunya adalah perkebunan cengkeh milik beberapa warga Kelurahan Kumelembuai. Warga yang memiliki lahan tersebut menjual lahan mereka untuk dialihfungsikan menjadi tempat wisata alam.

Pembangunan wisata alam Bukit Tetetana dengan mengalih fungsikan lahan yaitu lahan cengkeh akan mempunyai dampak, baik itu positif maupun negatif terutama bagi petani pemilik lahan yang mengalih fungsikan lahan tersebut, dimana dampak merupakan suatu perubahan yang sangat mendasar akibat adanya suatu kegiatan.

\section{Lahan}

Lahan adalah suatu lingkungan fisik yang meliputi tanah, iklim, relief, hidrologi, dan vegetasi, dimana faktor - faktor tersebut mempengaruhi potensi penggunaannya, Termasuk di dalamnya adalah akibat-akibat kegiatan manusia, baik pada masa lalu maupun sekarang, seperti reklamasi daerahdaerah pantai, penebangan hutan, dan akibatakibat yang merugikan seperti erosi dan akumulasi garam (Hardjowigeno, 2001). Lahan merupakan sumberdaya pembangunan yang memiliki karakteristik ketersediaan atau luasnya relatif tetap karena perubahan luas akibat proses alami (sedimentasi) dan proses 
artifisial (reklamasi) sangat kecil. Kesesuaian lahan dalam menampung kegiatan masyarakat juga cenderung bersifat spesifik karena lahan memiliki perbedaan sifat fisik seperti jenis batuan, kandungan mineral, topografi dan lain sebagainya. Menurut Notohadiprowiro dalam (I made, 2014), Permintaan lahan dipengaruhi oleh dua jenis permintaan yaitu direct demand (permintaan langsung) dan derived demand (pendorong permintaan). direct demand, lahan berfungsi sebagai barang konsumsi atau untuk pemukiman dan secara langsung memberikan utilitas. Melalui derived demand, peningkatan jumlah penduduk akan meningkatkan permintaan barang dan jasa sebagai alat pemuas kebutuhan. Untuk memproduksi barang dan jasa tersebut diperlukan lahan sebagai faktor produksi dimana lahan ini tidak memberikan utilitas secara langsung tetapi diperoleh dari konsumsi barang dan jasa.

\section{Penggunaan Lahan}

Penggunaan lahan (land use) dan penutupan lahan (landcover) pada hakekatnya berbeda walaupun sama-sama menggambarkan keadaan fisik permukaan bumi. Lillesand dan Kiefer dalam Haryani, (2011) mendefinisikan penggunaan lahan berhubungan dengan kegiatan manusia pada suatu bidang lahan, sedangkan penutupan lahan lebih merupakan perwujudan fisik obyek-obyek yang menutupi lahan tanpa mempersoalkan kegiatan manusia terhadap obyek-obyek tersebut. Sistem penggunaan lahan dikelompokkan menjadi 2 kelompok besar yaitu penggunaan lahan pertanian dan penggunaan lahan non pertanian. Penggunaan lahan pertanian antara lain, tegalan, sawah, ladang, kebun, padang rumput, hutan produksi, hutan lindung dan sebagainya. Penggunaan lahan non pertanian antara lain penggunaan lahan perkotaan atau pedesaaan, industri, rekreasi, pertambangan dan sebagainya (Arsyad dalam Haryani, 2011).

\section{Alih Fungsi Lahan}

Alih fungsi lahan adalah perubahan fungsi sebagian atau seluruh kawasan lahan dari fungsinya semula (seperti yang direncanakan) menjadi fungsi lain yang menjadi dampak negatif (masalah) terhadap lingkungan dan potensi lahan itu sendiri (Lestari, 2010). Sihaloho (2007) menjelaskan bahwa konversi lahan adalah alih fungsi lahan khususnya dari lahan pertanian ke non-pertanian atau dari lahan non pertanian ke lahan pertanian. Alih fungsi lahan adalah pengalokasian sumberdaya lahan dari satu penggunaan ke penggunaan lainnya.

Alih fungsi lahan adalah perubahan fungsi penggunaan lahan dari fungsi semula ke penggunaan lain atau perubahan fungsi lahan pertanian menjadi lahan non pertanian seperti lahan pertanian yang diubah menjadi kawasan wisata alam.

\section{Faktor - Faktor yang Mempengaruhi Alih Fungsi Lahan Pertanian}

Alih fungsi lahan pertanian ke penggunaan nonpertanian yang terjadi disebabkan oleh beberapa faktor (Lestari, 2010). Tiga faktor penting yang menyebabkan terjadinya konversi lahan pertanian yaitu sebagai berikut:

1. Faktor eksternal merupakan faktor yang disebabkan oleh adanya dinamika pertumbuhan perkotaan dan pertumbuhan penduduk, demografi maupun ekonomi.

2. Faktor internal merupakan faktor yang lebih melihat sisi yang disebabkan oleh kondisi sosial-ekonomi rumah tangga pertanian pengguna lahan.

3. Faktor kebijakan merupakan aspek regulasi yang dikeluarkan oleh pemerintah pusat maupun daerah yang berkaitan dengan perubahan fungsi lahan pertanian.

Alih fungsi lahan ke sektor non pertanian dapat terjadi karena para petani merasa pendapatan yang di dapatkan dari hasil pertanian dirasa kurang. Ini bisa terjadi karena, semakin lama tingkat kesuburan lahan pertanian yang semakin berkurang.

\section{Dampak Alih Fungsi Lahan Pertanian}

Menurut Priyono, (2012) dampak alih fungsi lahan pertanian, yaitu:

a) Dengan adanya alih fungsi lahan maka secara langsung memusnahkan lahan pertanian yang mengakibatkan semakin menyempitnya lahan pertanian, berkurangnya pendapatan petani, bahkan 
menghilangkan mata pencaharian buruh tani.

b) Dengan adanya kebijakan pemerintah, yang sebagian besar lahan yang di gunakan merupakan areal pertanian, maka hal tersebut tentunya menimbulkan sentimen masyarakat terhadap pemerintah, karena pemerintah dianggap tidak memikirkan kehidupan masyarakat petani.

\section{Pengertian Pariwisata}

Undang - Undang No. 10 Tahun 2009 Pasal 1 butir 3 dimana yang dimaksud dengan pariwisata adalah berbagai macam kegiatan wisata dan didukung berbagai fasilitas serta layanan yang disediakan oleh masyarakat, pengusaha, pemerintah dan pemerintah daerah. pengertian kepariwisatan menurut Undang - Undang No. 10 tahun 2009 pasal 1 angka 4 adalah keseluruhan kegiatan yang terkait dengan pariwisata dan bersifat multi dimensi serta multi disiplin yang muncul sebagai wujud kebutuhan setiap orang dan negara, serta interaksi antara wisatawan dan masyarakat setempat, sesama wisatawan, pemerintah, pemerintah daerah dan pengusaha.

\section{Dampak Perkembangan Pariwisata}

Pariwisata akan memberikan dampak baik positif maupun negatif, dan yang terkena dampak tersebut adalah masyarakat, lingkungan, ekonomi, sosial. Dampak perkembangan pariwisata (Mill dalam Paramitasari, 2010).

1. Dampak Segi lingkungan Positif:

a) Terpeliharanya kebersihan alam dan lingkungan untuk menarik wisatawan

b) Terjaganya keistimewaan lingkungan seperti hutan, pantai, dan pemandangan alam

Negatif:

a) Lingkungan yang rusak seperti: meningkatnya kadar polusi

b) Pembukaan hutan untuk lahan pertanian, lahan pemukiman
2. Dampak sosial budaya

Positif:

a) Terpeliharanya monument yang menyimpan nilai-nilai budaya dan tempat tempat bersejarah

b) Terpeliharanya kebudayaan tradisional, seni, tarian, adat istadat, dan cara berpakaian

Negatif:

a) Rusaknya monument dan tempat bersejarah karena ulah manusia

b) Komersilisasi budaya

c) Meningkatnya kriminalitas, konsumersime masyarakat lokal, dan pelacuran.

3. Dampak ekonomi

Positif:

a) Terbukanya lapangan pekerjaan baru

b) Meningkatkan taraf hidup dan pendapatan masyarakat

c) Meningkatkan nilai tukar rupiah terhadap mata uang asing

d) Membantu membangun tempat sarana dan prasarana setempat

e) Meningkatkan kemampuan manajerial dan keterampilan masyarakat untuk memacu kegiatan ekonomi lainnya

Negatif:
a) Meningkatkan biaya pembangunan sarana dan pra sarana
b) Meningkatkan harga barang barang lokal dan bahan pokok
c) Peningkatan yang sangat tinggi tapi hanya musiman, sehingga pendapatan masyarakat naik turun.

\section{Karakteristik Sosial Ekonomi Petani}

Faktor sosial ekonomi adalah faktor-faktor yang berasal dari segi sosial dan ekonomi yang dimiliki petani sehingga dapat mempengaruhi mereka mengenai suatu hal. Petani adalah semua orang yang berdiam di pedesaan yang mengelola usaha pertanian (Wulandari, 2013). Karakteristik sosial - 
ekonomi petani Menurut Hartanto dalam Ante (2016):

1. Umur

Umur petani akan mempengaruhi kemampuan fisik dan respon terhadap hal-hal yang baru dalam menjalankan usaha taninya.

\section{Tingkat pendidikan}

Pendidikan merupakan proses timbal balik dari setiap pribadi manusia dalam penyesuaian dirinya dengan alam, teman dan alam semesta Mardikanto (1993). Suhardiyono (1992) menjelaskan bahwa para ahli pendidikan mengenal 3 sumber pengetahuan, yaitu:

a. Pendidikan Informal: proses pendidikan yang panjang, diperoleh daan dikumpulkan oleh seseorang berupa pengetahuan, keterampilan, sikap hidup, dan segala sesuatu yang diperoleh dari pengalaman pribadi sehari-hari dari kehidupannya dalam masyarakat.

b. Pendidikan Formal: struktur dari suatu sistem pengajaran yang kronologis dan berjenjang lembaga pendidikan mulai dari pra sekolah sampai dengan perguruan tinggi.

c. Pendidikan Non-formal: pengajaran sistematis yang diorganisir dari luar sistem pendidikan formal bagi sekelompok orang untuk memenuhi keperluan khusus. Salah satu contoh pendidikan non-formal ini adalah penyuluhan pertanian.

Pendidikan dapat diperoleh melalui pendidikan informal, formal maupun nonformal, keterbatasan pengetahuan yang dimiliki petani biasanya akan menjadi hambatan. Tingkat pendidikan petani baik informal, formal maupun non formal akan mempengaruhi cara berfikir yang diterapkan pada usahanya yaitu dalam rasionalisasi usaha dan kemampuan memanfaatkan setiap kesempatan yang ada.

\section{Pendapatan}

Pendapatan merupakan faktor yang sangat penting dalam menunjang perekonomian keluarga. Tingkat pendapatan merupakan salah satu indikasi sosial ekonomi seseorang dalam masyarakat di samping pekerjaan, kekayaan dan pendidikan. Keputusan seseorang dalam memilih pekerjaan dipengaruhi oleh sumberdaya dan kemampuan dalam diri individu.

\section{Perumusan Masalah}

Berdasarkan uraian dari latar belakang di atas maka masalah yang akan diteliti adalah Bagaimana dampak alih fungsi lahan pertanian cengkeh terhadap kondisi sosial ekonomi petani ?

\section{Tujuan Penelitian}

Tujuan dari penelitian untuk mendeskripsikan dampak alih fungsi lahan pertanian cengkeh terhadap kondisi sosial ekonomi petani pemilik lahan.

\section{Manfaat Penelitian}

Manfaat dari penelitian ini :

1. Untuk Pemerintah

Kiranya dapat menjadi bahan informasi dan pertimbangan untuk pemerintah dalam pengambilan keputusan mengenai alih fungsi lahan di Kelurahan Kumelembuai.

\section{Untuk Masyarakat}

Dapat memberikan informasi mengenai dampak alih fungsi lahan pertanian cengkeh terhadap kondisi sosial ekonomi petani pemilik lahan.

3. Untuk Peneliti

Peneliti kiranya dapat menambah pengetahuan dan wawasan serta dapat mengaplikasikan teori yang didapat selama studi

\section{METODOLOGI PENELITIAN}

\section{Waktu dan Tempat Penelitian}

Pengambilan data primer dan sekunder dalam penelitian ini dilaksanakan selama 3 bulan mulai dari bulan Mei sampai Juli 2017, mulai dari persiapan sampai penyusunan laporan hasil penelitian. Penelitian ini dilakukan di tempat wisata alam Bukit 
Tetetana di Kelurahan Kumelembuai Kecamatan Tomohon Timur Kota Tomohon.

\section{Metode Pemilihan Sampel}

Metode pemilihan sampel menggunakan metode purposive sampling. Pemilihan sampel pada penelitian ini yaitu kepada 5 responden yang menjual lahannya untuk di alih fungsikan di kawasan obyek wisata.

\section{Jenis dan Sumber Data}

Data yang dikumpulkan dari penelitian ini ada 2 jenis yaitu: data primer dan data sekunder. Data primer yang diambil dalam penelitian ini berasal dari wawancara langsung pada petani pemilik lahan yang telah menjual lahannya untuk di alih fungsikan menjadi kawasan obyek wisata alam dengan wawancara menggunakan daftar pertanyaan yang telah disusun, wawancara dengan pengelola tempat wisata, dan observasi. Data sekunder yang dikumpulkan dari Instansi pemerintah yaitu Badan Pusat Statistik melalui website, Kelurahan Kumelembuai.

\section{Konsepsi Variabel Penelitian}

Variabel yang digunakan dalam penelitian ini adalah :

\section{Faktor - Faktor Yang Mempengaruhi Alih Fungsi Lahan :}

1. Faktor Eksternal meliputi :
a) Faktor Demografi
b) Faktor Lokasi Wisata yang Strategis
c) Faktor Ekonomi
d) Faktor Iklim

2. Faktor Internal meliputi :
a) Pendapatan petani sebelum dan sesudah alih fungsi lahan
b) Pendapatan hasil panen terakhir kebun cengkeh

\section{Dampak Alih Fungsi Lahan :}

1. Dampak Ekonomi meliputi :
a) Peningkatan pendapatan keluarga petani ( Positif )
b) Pembangunan rumah petani ( Positif )
c) Usaha pertanian baru bagi keluarga petani ( Positif)

d) Menambah modal dagang ( Positif )

e) Peluang bekerja untuk masyarakat ( Positif )

2. Dampak Sosial meliputi :
a) Perubahan status hidup keluarga petani ( Positif)
b) Kebiasaan pengunjung terhadap masyarakat ( Negatif).

\section{Analisis Data}

Analisis yang dipakai dalam penelitian ini adalah Analisis Deskriptif, yaitu mendeskripsikan dampak sosial ekonomi petani terhadap alih fungsi lahan pertanian cengkeh menjadi tempat wisata alam dalam bentuk tabel serta menyusun dan menyajikan data dalam informasi yang jelas.

\section{HASIL DAN PEMBAHASAN}

\section{Deskripsi Lokasi Penelitian}

\section{Deskripsi Kelurahan Kumelembuai}

Kelurahan Kumelembuai terletak di Kecamatan Tomohon Timur Kota Tomohon. Kelurahan Kumelembuai terletak di atas ketinggian $\pm 1100 \mathrm{mdpl}$ (meter di atas permukaan laut). Kelurahan Kumelembuai memiliki luas wilayah \pm 330 hektar dengan lahan pemukiman hanya 10 hektar. Batas wilayah administratif Kelurahan Kumelembuai adalah Sebelah utara berbatasan dengan Desa Suluan, Sebelah selatan berbatasan dengan Kelurahan Rurukan, Sebelah barat berbatasan dengan Hutan Lindung Gunung Mahawu, dan Sebelah timur berbatasan dengan Kabupaten Minahasa.

\section{Deskripsi Obyek Wisata}

Obyek wisata alam "Bukit Tetetana" merupakan milik Keluarga Korompis Mewengkang yang mulai dibuka pada 1 Januari 2017. Wisata alam ini terletak di atas perbukitan di ketinggian \pm 1100 mdpl (meter di atas permukaan laut) memiliki suhu yang dingin dan berkabut tebal jika hujan. Obyek wisata ini masuk dalam wilayah kepolisian Desa Suluan Kabupaten Minahasa. Tanah 
dalam obyek wisata ini dulunya milik beberapa warga Kumelembuai sebelum dialihfungsikan. Obyek wisata ini masih dalam proses pembangunan, dan belum selesai. Obyek wisata ini memiliki tenaga kerja sebanyak empat puluh orang yang berasal dari warga Kumelembuai, dan sebagian warga Rurukan. Akses ke obyek wisata ini melalui Kelurahan Kumelembuai. Fasilitas yang dimiliki obyek wisata ini adalah satu bangunan pondok bambu, lahan parkir, pondok tempat tinggal pengelola, taman bunga dan kolam ikan.

\section{Deskripsi Responden}

Total responden sebanyak lima (5) orang yang mengalihfungsikan lahannya. Tabel 1 adalah pengelompokan responden menurut kelompok umur.

Tabel 1 menunjukkan tingkat umur responden didominasi oleh responden dengan umur 51-60 tahun sebesar 60 persen dan responden umur 41-50 sebesar 40 persen. Umur petani akan mempengaruhi kemampuan fisik dan respon terhadap halhal yang baru dalam menjalankan usaha taninya.

Tabel 2 menunjukkan bahwa tingkat pendidikan responden yaitu SMP sebesar 40 persen selanjutnya diikuti SMA sebesar 40 persen, dan yang terakhir S1 sebesar 20 persen. Pendidikan dapat diperoleh melalui pendidikan informal, formal maupun nonformal, keterbatasan pengetahuan yang dimiliki petani biasanya akan menjadi hambatan. Tingkat pendidikan petani baik informal, formal maupun non-formal akan mempengaruhi cara berfikir yang diterapkan pada usahanya yaitu dalam rasionalisasi usaha dan kemampuan memanfaatkan setiap kesempatan yang ada (Paramitasari 2010). Keseluruhan responden tidak mengetahui tentang alih fungsi lahan, sehingga mempengaruhi keputusan responden untuk menjual lahannya.

Tabel 3 menunjukkan jenis pekerjaan responden yang berbeda-beda, didominasi oleh jenis pekerjaan Petani sebesar 60 persen, dan yang terakhir Swasta dan PNS masing- masing sebesar 20 persen. Pekerjaan responden yaitu swasta dan PNS mempengaruhi penjualan lahan mereka untuk dialih fungsikan. lahan kebun cengkeh yang dimiliki sudah tidak pernah dirawat lagi, karena pekerjaan utama adalah bekerja sebagai Swasta dan PNS. Bertani sudah tidak menjadi pekerjaan utama responden, bertani hanya menjadi pekerjaan sampingan responden, sehingga mempengaruhi responden untuk manjual lahan tersebut.

Responden yang bekerja sebagai petani tetap bekerja sebagai petani meskipun telah menjual lahan kebun cengkeh. Responden yang tetap bekerja sebagai petani karena masih memiliki kebun lain yang masih dapat diolah sehingga petani masih menjadi pekerjaan utama responden tersebut.

Tabel 4 menunjukkan kepemilikan lahan dan total luas lahan yang dijual. Rata-rata lahan yang dijual responden merupakan lahan milik pribadi. Rata-rata lahan tersebut didapatkan dari warisan orang tua.

Kepemilikan lahan salah satu responden adalah tanah kalakeran atau milik keluarga besar yang belum dibagi. Meskipun lahan tersebut merupakan lahan milik kakak beradik, namun semua hasil penjualannya oleh saudara-saudaranya diberikan kepada responden berdasarkan kesepakatan yang dibuat.

\section{Faktor - Faktor Yang Mempengaruhi Alih Fungsi Lahan Pertanian}

\section{Faktor Eksternal}

\section{a. Faktor Demografi}

Meningkatnya jumlah penduduk mengakibatkan meningkatnya kebutuhan lahan antara lain untuk tempat tinggal dan tempat usaha yang diambil dari lahan milik generasi sebelumnya atau tanah negara. Hal ini jelas akan menyempitkan/mengurangi luas tanah disamping adanya keinginan generasi berikutnya merubah lahan pertanian yang sudah ada, meskipun dalam penelitan ini yang memiliki keinginan untuk mengubah fungsi lahan pertanian adalah investor yang membeli lahan tersebut. 


\section{b. Faktor Lokasi Wisata yang Strategis}

Lokasi Wisata alam ini berada di dataran tinggi \pm 1100 mdpl (meter di atas permukaan laut), memiliki suhu yang dingin dan berkabut dan berada di kawasan perkebunan yang dimiliki oleh warga Kelurahan Kumelembuai yang terletak di wilayah kepolisian Desa Suluan (Pejabat Kelurahan Kumelembuai, 2017). Lokasi wisata alam ini tidak jauh dari Kelurahan Kumelembuai \pm 1 kilometer. Akses jalan ke tempat wisata alam ini sudah ada dari dahulu karena merupakan jalan kebun warga Kumelembuai. Wisata alam ini memiliki sudut pandang yang luas yaitu Gunung Mahawu, Kota Manado, Minahasa Utara, dan Kota Bitung. Letak wisata alam yang strategis ini membuat investor tertarik untuk membeli lahan di tempat itu dan membuat menjadi tempat wisata alam.

\section{c. Faktor Ekonomi}

Pendapatan hasil pertanian kebun cengkeh dinilai petani merugikan, karena biaya pengeluaran tidak sebanding dengan hasil yang didapat saat panen. Hasil panen yang didapat sangat rendah sehingga mendorong petani untuk menjual lahan tersebut.

Harga yang ditawarkan investor sangat tinggi, jauh lebih tinggi dari harga tanah yang biasa diperjualbelikan di Kelurahan Kumelembuai dan petani mendapatkan uang dalam jumlah besar sekaligus. Harga tanah yang tinggi yang diawarkan investor mendorong mereka untuk menjual lahan pertanian tersebut.

Tabel 5 menggambarkan luas lahan yang dijual oleh responden dan harga yang dibayar investor kepada responden. Tabel 5 memuat data tentang harga yang dibayarkan pihak investor ke pemilik lahan. Terjadi perbedaan harga yang dibayarkan pihak investor diduga karena letak tanah yang lebih strategis atau lebih baik dari yang lain. Responden 1 yang kepemilikan lahannya milik keluarga, menerima seluruh total harga pembayaran yang dibayar investor karena sudah meminta persetujuan dari seluruh keluarga pemilik lahan tersebut.

\section{Faktor Internal}

Faktor internal jauh lebih melihat sisi yang disebabkan oleh kondisi sosial-ekonomi rumah tangga petani pengguna lahan.

\section{a. Pendapatan Keluarga Petani}

Pendapatan merupakan faktor yang sangat penting dalam menunjang perekonomian keluarga. Tingkat pendapatan merupakan salah satu indikasi sosial ekonomi seseorang dalam masyarakat di samping pekerjaan, kekayaan dan pendidikan. Responden yang telah mengalihfungsi lahan pertanian menjadi obyek wisata memiliki pendapatan yang tidak tetap setiap bulannya.

Tabel 6 menunjukkan data tentang pendapatan petani yang diterima petani sebelum lahan mereka dijual dan pada saat mereka menerima uang hasil penjualan lahan mereka atau pendapatan dari hasil alih fungsi lahan.

Pendapatan petani sebelum melakukan alih fungsi lahan sekitar 3 juta sampai dengan 10 juta rupiah per bulan. Setelah melakukan alih fungsi lahan atau menjual lahan, petani mendapatkan pendapatan yang lebih tinggi. Seluruh responden mengalami perubahan pendapatan pada waktu mereka menjual lahan kebun. Harga yang lebih tinggi dari harga pasar yang ditawarkan investor mendorong responden untuk menjual lahan kebun.

Pengelolaan hasil pendapatan dari alih fungsi lahan yang jika dikelola petani dengan baik akan berdampak baik bagi petani itu sendiri. Hasil penelitian menunjukkan ratarata responden menggunakan pendapatan dari hasil alih fungsi lahan untuk memperbaiki dan membuat bangunan rumah. Hanya responden 4 yang menggunakan hasil penjualan lahan untuk membeli lahan kebun yang baru.

\section{b. Pendapatan dari Hasil Panen Terakhir Kebun dari Kebun Cengkeh}

Pendapatan hasil panen terakhir kebun cengkeh sesuai hasil wawancara, hanya ada dua responden yang melakukan panen terakhir yaitu responden 1 dan 4 . Panen terakhir responden 1 yaitu pada tahun 2000 dengan hasil yang didapat Rp.5.000.000 dan responden 4 pada tahun 2015 dengan hasil yang didapat Rp.1.425.000. Responden 2 
belum pernah panen karena cengkeh yang ditanam masih sangat muda dan sudah dijual. Responden 5 tidak mengetahui hasil panen terakhir. Responden 6 belum pernah melakukan panen karena sejak diwariskan 3 tahun yang lalu dan cengkeh didalam kebun tersebut sudah tua menurut responden.

Hasil penelitian dapat menyimpulkan bahwa pendapatan hasil panen terakhir kebun cengkeh hanya dilakukan oleh dua responden. Hasil panen tersebut tidak sebanding dengan biaya yang dikeluarkan petani, sehingga mempengaruhi keputusan responden untuk menjual lahannya.

\section{Dampak Alih Fungsi Lahan Pertanian Dampak Ekonomi \\ - Positif}

\section{a. Meningkatkan Pendapatan Keluarga Petani}

Alih fungsi lahan yang terjadi mempengaruhi pendapatan petani. Hal ini dapat dilihat pada Tabel 6 Pendapatan petani setelah mangaihfungsikan lahan atau menjual lahan berubah karena harga yang dibayarkan investor sangat tinggi jauh berbeda dari harga lahan yang biasa diperjualbelikan di Kelurahan Kumelembuai.

\section{b. Pembangunan Rumah Keluarga Petani}

Berdasarkan hasil penelitian, empat dari 5 responden menggunakan hasil penjualan lahan untuk membangun sarana dan prasarana rumah. Dua responden menggunakan semua hasil penjualan lahan mereka hanya untuk membangun rumah

Tabel tujuh menunjukkan data tentang pendapatan petani yang diterima petani sebelum lahan mereka dijual dan pada saat mereka menerima uang hasil penjualan lahan mereka atau pendapatan dari hasil alih fungsi lahan.

Pendapatan petani sebelum melakukan alih fungsi lahan sekitar 3 juta sampai dengan 10 juta rupiah per bulan. Setelah melakukan alih fungsi lahan atau menjual lahan, petani mendapatkan pendapatan yang lebih tinggi. Seluruh responden mengalami perubahan pendapatan pada waktu mereka menjual lahan kebun. Harga yang lebih tinggi dari harga pasar yang ditawarkan investor mendorong responden untuk menjual lahan kebun.

Pengelolaan hasil pendapatan dari alih fungsi lahan yang jika dikelola petani dengan baik akan berdampak baik bagi petani itu sendiri. Hasil penelitian menunjukkan ratarata responden menggunakan pendapatan dari hasil alih fungsi lahan untuk memperbaiki dan membuat bangunan rumah. Hanya responden 4 yang menggunakan hasil penjualan lahan untuk membeli lahan kebun yang baru.

\section{c. Pembangunan Rumah Keluarga Petani}

Berdasarkan hasil penelitian, empat dari 5 responden menggunakan hasil penjualan lahan untuk membangun sarana dan prasarana rumah. Dua responden menggunakan semua hasil penjualan lahan mereka hanya untuk membangun rumah.

Tabel 6 menunjukkan rata rata pengelolaan hasil penjualan lahan digunakan untuk membangun dan memperbaiki rumah.

\section{d. Membuka Usaha pertanian Baru Keluarga Petani}

Hasil penjualan lahan oleh petani dimanfaatkan untuk membuka usaha pertanian yang baru. Lahan pertanian yang baru dimanfatkan untuk menanam tanaman jangka pendek misalnya wortel dan kol yang penghasilannya telah dirasakan oleh keluarga petani. Hasil dari alih fungsi lahan berdampak positif dengan memanfaatkan penjualan lahan untuk membeli lahan yang baru.

\section{e. Menambah Modal Usaha}

Hasil dari penjualan lahan mempengaruhi usaha responden. usaha yang dilakukan responden satu adalah penjual bahan keliling menggunakan mobil. pengelolaan hasil penjualan lahan digunakan responden satu untuk menambah modal dagangannya sehingga dagangannya menjadi lebih besar.

\section{f. Peluang Kerja Untuk Masyarakat Sekitar}

Dengan adanya pembangunan obyek wisata alam "Bukit Tetetana", kesempatan kerja bagi warga masyarakat Kelurahan Kumelembuai 
meningkat. Tenaga kerja yang bekerja di kawasan wisata alam sebagian besar berasal dari Kelurahan Kumelembuai. Jenis pekerjaan tersebut berupa merawat tanaman, menjaga pos masuk, dan membuka usaha berupa warung makanan dan minuman yang menyerap sekitar 40 orang.

\section{Dampak Sosial}

\section{- Positif}

\section{a. Perubahan Status Hidup Keluarga Petani}

Alih fungsi lahan yang terjadi berdampak positif terhadap keluarga petani. Hasil dari penjualan lahan digunakan oleh petani untuk membangun rumah sendiri. Keluarga petani yang sebelumnya menempati rumah milik orang sekarang sudah menempati rumah sendiri. Alih fungsi lahan yang terjadi berpengaruh positif terhadap perubahan satus hidup keluarga petani.

\section{- Negatif}

\section{b. Kebiasaan Pengunjung Terhadap Masayarakat}

Berdasarkan hasil penelitian, peningkatan kunjungan wisatawan yang datang ke lokasi wisata, memberi dampak negatif terhadap nilai budaya dan norma yang berlaku di masyarakat. Dimana perbedaan budaya dan norma yang berlaku memiliki perbedaan seperti gaya berpakaian dan gaya bahasa dalam berkomunikasi. Jika terus berlangsung hal ini akan membawa dampak terhadap kebiasaan pada masyarakat lokal yang ada disekitar kawasan wisata.

Tabel 1. Responden Menurut Kelompok Umur

\begin{tabular}{ccc}
\hline Tingkat Umur & Jumlah Responden & Persentase (\%) \\
\hline $41-50$ & 2 & 40 \\
$51-60$ & 3 & 60 \\
\hline Total & 5 & 100 \\
\hline
\end{tabular}

Sumber : Data Primer (2017)

Tabel 2. Responden Menurut Tingkat Pendidikan

\begin{tabular}{ccc}
\hline Tingkat Pendidikan & Jumlah Responden & Persentase (\%) \\
\hline SMP & 2 & 40 \\
SMA & 2 & 40 \\
S1 & 1 & 20 \\
\hline Total & 5 & 100 \\
\hline
\end{tabular}

Sumber : Data Primer (2017)

Tabel 3. Responden Menurut Jenis Pekerjaan

\begin{tabular}{ccc}
\hline Pekerjaan & Jumlah Responden & Persentase $(\%)$ \\
\hline Swasta & 1 & 20 \\
Petani & 3 & 60 \\
PNS & 1 & 20 \\
\hline Total & 5 & 100 \\
\hline
\end{tabular}

Sumber : Data Primer (2017)

Tabel 4. Kepemilikan Lahan dan Total Luas Lahan yang Di Jual

Responden Kepemilikan Lahan
Total Luas Lahan Yang Dijual (hektar)

\begin{tabular}{ccc}
\hline $\mathbf{1}$ & Kalakeran (lahan milik bersama) & $0.4 \mathrm{Ha}$ \\
$\mathbf{2}$ & Passini (lahan milik pribadi) & $0.36 \mathrm{Ha}$ \\
$\mathbf{4}$ & Passini (lahan milik pribadi) & $0.44 \mathrm{Ha}$ \\
$\mathbf{5}$ & Passini (lahan milik pribadi) & $0.45 \mathrm{Ha}$ \\
$\mathbf{6}$ & Passini (lahan milik pribadi) & $0.28 \mathrm{Ha}$ \\
\hline
\end{tabular}


Tabel 5. Total Luas Lahan yang Dijual, dan Harga yang Dibayar Investor

\begin{tabular}{ccc}
\hline Responden & Total luas lahan yang dijual & Harga yang dibayar (juta) \\
\hline $\mathbf{1}$ & $0.4 \mathrm{Ha}$ & 80 \\
$\mathbf{2}$ & $0.36 \mathrm{Ha}$ & 165 \\
$\mathbf{4}$ & $0.44 \mathrm{Ha}$ & 135 \\
$\mathbf{5}$ & $0.45 \mathrm{Ha}$ & 120 \\
$\mathbf{6}$ & $0.28 \mathrm{Ha}$ & 70 \\
\hline
\end{tabular}

Sumber : Data Primer (2017)

Tabel 6. Pendapatan Petani Sebelum dan Sesudah Alih Fungsi Lahan

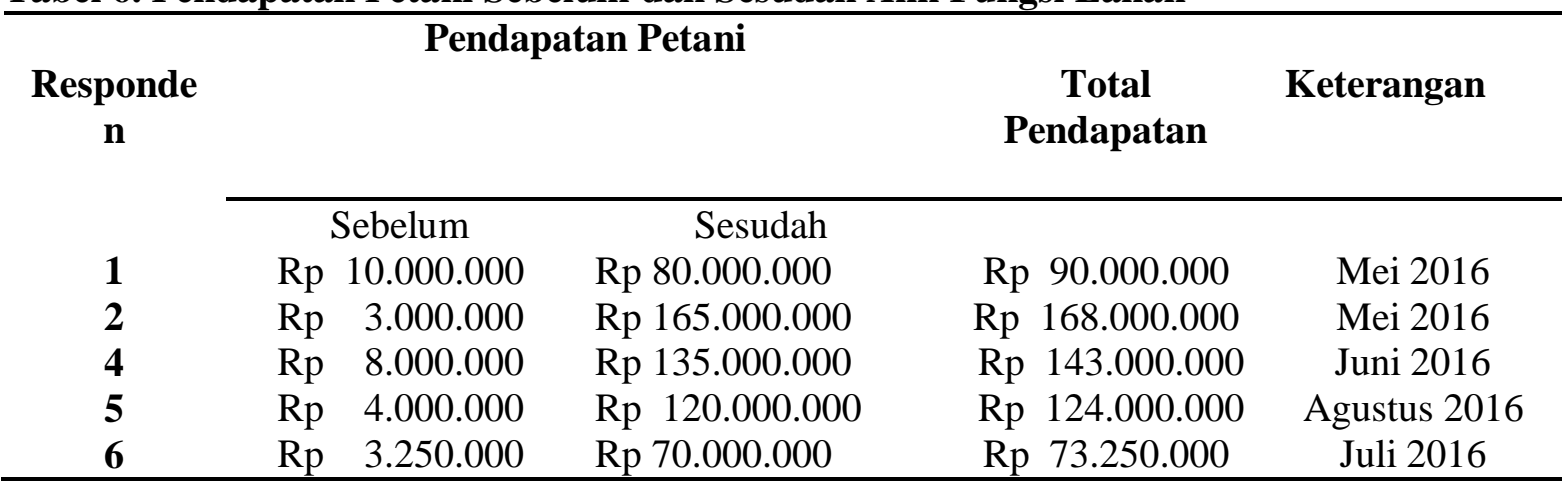

Sumber : Data Primer (2017)

\section{KESIMPULAN DAN SARAN}

\section{Kesimpulan}

Hasil penelitian menunjukkan dampak dari alih fungsi lahan dilihat dari sisi ekonomi, alih fungsi lahan berdampak positif bagi keluarga petani dan masyarakat sekitar. Bagi keluarga petani: meningkatkan pendapatan keluarga petani, pembangunan rumah keluarga petani, membuka usaha pertanian baru bagi keluarga petani. Untuk masyarakat membuka peluang kerja untuk masyarakat sekitar. Dilihat dari sisi sosial alih fungsi lahan berdampak positif dan negatif yaitu: berdampak positif dengan terjadinya perubahan status hidup keluarga petani karena memiliki rumah sendiri (positif), dan kebiasaan pengunjung terhadap masyarakat (negatif), berupa cara berpakaian dan cara bertutur kata yang tidak sesuai dengan kesopanan pada budaya Minahasa.

\section{Saran}

Berdasarkan hasil penelitian ini, maka saran yang dapat diberikan adalah pendapatan dari hasil alih fungsi lahan sebaiknya digunakan untuk kegiatan produktif dan bukan konsumtif sehingga memberikan dampak yang lebih bagi bagi petani dan keluarga petani itu sendiri.

\section{DAFTAR PUSTAKA}

Ante, Elisabeth, Noortje M. Benu, and Vicky R. B Moniaga (2016). "Dampak Ekonomi Dan Sosial Alih Fungsi Lahan Pertanian Holtikultura di Kelurahan Kumelembuai Kecamatan Tomohon Timur Kota Tomohon." AGRI-SOSIO EKONOMI.

Badan Pusat Statistik (2015). Jumlah Penduduk di Indonesia. 
I Made, Dwipradnyana, (2014). Faktorfaktor yang Mempengaruhi Konversi Lahan Pertanian Serta Dampaknya Terhadap Kesejahteraan Petani Subak, Kecamatan Kediri, Tabanan. Tesis. Denpasar. Program Pascasarjana Universitas Udayana, Denpasar.

Hardjowigeno, S. dan Widiatmaka. (2001). "Evaluasi Kesesuaian Lahan dan Perencanaan Tataguna Lahan.

Ilham, Nyak, Yusman Syaukat, and Friyatno (2005). "Perkembangan Dan FaktorFaktor Yang Mempengaruhi Konversi Lahan Sawah Serta Dampak Ekonominya." SOCA (SocioEconomic of Agriculture and Agribusiness).

Lestari, Tri (2010). "Konversi Lahan Pertanian dan Perubahan Taraf Hidup Rumah tangga Petani: Kasus Pembangunan Perumahan $X$ di Kampung Cibeureum Sunting dan Kampung Pabuaran, Kelurahan Mulyaharja, Kecamatan Bogor Selatan, Kota Bogor, Provinsi Jawa Barat."

/l
Paramitasari, Isna Dian (2010). Dampak Pengembangan Pariwisata Terhadap kehidupan masyarakat lokal Studi Kasus: Kawasan Wisata Dieng Kabupaten Wonosobo Universitas Sebelas Maret.

Priyono. (2012). Alih Fungsi Lahan Pertanian Merupakan Suatu Kebutuhan Atau Tantangan. Jurnal Ilmiah Fakultas Pertanian UNINSRI Surakarta.

Suhardiyono, L. (1992). Penyuluhan. Petunjuk bagi Penyuluhan Pertanian. Jakarta: Erlangga.,

Sihaloho, Martua., Dharmawan, Arya Hadi, dan Rusli, Said. (2007). Konversi Lahan Pertanian dan Perubahan Struktur Agraria (Studi Kasus di Kelurahan Mulyaharaja, Kecamatan Bogor Selatan, Kota Bogor, Jawa barat). Jurnal Trans disiplin Sosiologi, Komunikasi, dan Ekologi Manusia Vol. 1. Tahun 2007. Jawa Barat.

Undang-Undang Republik Indonesia Nomor 10 Tahun 2009 tentang Kepariwisataan.

Wulandari, (2013). Kondisi Sosial Ekonomi Petani Padi Sawah di Kelurahan Mangalli, Kecamatan Pallangga.

(http://waraneytoundanouw.blogspot.co.id/2 $\underline{015 / 01 /}$ (diakses tanggal 25 oktober 2017) 